\title{
EMPIRIC DEMOCRACY AND THE REFERENCE OF POLITICAL PARTIES IN SINGLE CANDIDATE ELECTIONS
}

\author{
Sulistyowati \\ Muria Kudus University \\ sulistyowati@umk.ac.id
}

\begin{abstract}
Abstrack
The dynamic changes in the Law on Election for Governors, Regents, and Mayors prove that there are dynamics and progressiveness in the implementation of Pilkada. The process of the birth of laws, including the process of the birth of amendments to the Law, is a legal political process. The legal political process is under the authority of the legislator. The approach method used is normative juridical method. The power of legislators in the political and legal process is not absolute, because the government also has a domain of authority, although not as big as the authority of legislators. The result states that The legal political process always rests on the principle of normative democracy as the embodiment of the das sollen principle. At the level of implementation of the rule of law, there will always be legal anomalies, because there is a mismatch between normative democracy as the embodiment of the basic principle with empirical democracy as the embodiment of the basic sein principle. The legitimacy of a single candidate in Law Number 10 of 2016 concerning the Election of Governors, Regents, and Mayors makes the preferences of political parties increasingly pragmatism.
\end{abstract}

Keywords: Empirical Democracy; Political Party Preferences; Single Candidate.

\section{A. INTRODUCTION}

After Indonesian independence was proclaimed, there were parties politics get legality through a signed Government Declaration Vice President Moh. Hatta, November 3, 1945. ${ }^{1}$ The implementation of democracy in a modern democracy is no longer true it may be carried out using the direct democracy model. There are many obstacles to be faced if direct democracy is to be implemented. Therefore, the implementation of democracy is carried out by representatives of the people who sit as a member of the People's Representative Body. ${ }^{2}$ Political parties are a necessity in modern democratic political life. $^{3}$

In a constitutional democracy in Indonesia, the existence of a political party is a necessity. The life of a political party can only be maintained in a conducive climate. Among other things, the representation of a democratic

1 Aiyub Mohsin, Partai Politik dan Sistem Demokrasi di Indonesia, Populis Journal, Volume 3 Number 6, 2018, page.778

2 Zaenal Abidin Saleh, Democracy and Political Parties, Legislasi Indonesia Journal, Volume 5 Number 1 Maret 2008, page.56.

3 A. Ganu Kadir, Dinamika Partai Politik, Sosiohumaniora Journal, Volume 16 Number 2 Juli 2014, page.132. 
country done through general elections. ${ }^{4}$ The appearance of the parties is proportional straight with the growth of the democratization process especially about equal rights citizen. ${ }^{5}$ In a democratic country, the relationship between the state and the people must be a reflection of a mutualistic symbiosis. This means that these relationships must be mutually dependent and mutually beneficial. This relationship will be evident when the political system developed by a country provides sufficient space for political activities in the community. ${ }^{6}$

The terminology of democracy is not only singular, Philosophers and Lawyers and Government Experts define democracy, it contains meanings and essences that are not much different. Democracy is a form of government in which all citizens, have equal rights in decision-making, which can change their lives. ${ }^{7}$ Adhere to the principles of protection law, protection of human rights for citizens country, and democratic principles, including protection of children, so it is absolute for state and government provide protection law and human rights to children as part of the nation's. ${ }^{8}$

In the era of democratic rule this time, role and involvement community to contribute to running the government is the main parameter which is can be seen as an order dignified power. ${ }^{9}$ Democracy has two sides, such as coins, democracy can be seen and analyzed from a theoretical aspect on the one hand, then from a practical aspect on the other. The general commitment to governance, including electing the regional head, is to achieve democratic regional head elections, both governors, regents, and mayors. ${ }^{10}$

Democracy is not only a principle but also a system of government that is claimed to be the best in the administration of political systems and government systems. Almost all of the experts in state administration have the same opinion that democracy, at the theoretical level, is good and guarantees people's participation. Both the participation of the people in

4 Ramly Hutabarat, Peranan Partai Politik Menyerap Aspirasi Masyarakat dan Hukum Politik yang Tidak Simantik, Hukum dan Pembangunan Journal, Volume 35 Number 3, 2005, page. 134.

5 Ridho Imawan Hanafi, Kemunculan dan Tantangan Partai Politik Baru Pada Pemilu 2019, Penelitian politik Journal, Volume 15 Number 2December 2018. page. 198

6 Udiyo Basuki, Parpol, Pemilu dan Demokrasi : Dinamika Parta Politik Dalam Sistem Pemilihan Umum di Indonesia Dalam Perspektif Demokrasi, Kosmik Journal, Volume 20, Number 2, 2020, page. 1 .

7 Jonathan Wolff, Filsafat Politik, Bandung, Nusamedia, 2013, page 89.

8 Ida Musofiana, Legal Protection For Victims Of Cybercrime In The Digital Era In Strengthening Cyber Democracy In Indonesia Post 2019 General Election, The 2nd Proceeding International Conference And Call Paper Sultan Agung Islamic University, "democracy in digital era : law, governance,sociall and economic perspective in Asia, Australia and Dutch", Volume 1, Number 1, 2020, page. 84

9 Agus Nurulyam Suparman, Gilang Yuniar Rahman, Partai Politik dan Kaderisasi, Moderat Journal, Volume Number 4, 2017, page. 200

10 David Held, Models of Democracy, Terjemahan Abdul Haris, Jakarta, Akbar Tandjung Institute, 2007, page. Xxxii. 
exercising their civil and political rights. Some problems have not reached an agreement, namely democracy at the level of implementation and practice. ${ }^{11}$

The phenomenon of democracy can be divided into two, namely normative democracy and empirical democracy. Normative democracy is only oriented to idealist ideas/thoughts at the philosophical level. On the other hand, empirical democracy is the implementation of normative democracy in the practice of the state, governance, and political system.

Observing the implementation of democratic practices, between normative democracy and empirical democracy, it is not always parallel, even a condition of legal anomalies can occur. In this reality, the term normative democracy is called the essence of democracy, and empirical democracy is called performance democracy. The link between normative democracy and empirical democracy, in law, is called the gap between das sollen and das sein.

Normative democracy gives meaning substantially, while empirical democracy procedurally gives meaning. The meaning of substantial democracy at the normative level should develop equality or egalitarian values, diversity or pluralism, respect for differences or tolerance, respect for human rights, freedom, togetherness, the right to be elected, and to choose and treatment without discrimination. Substantively, democracy transcends its meaning politically. ${ }^{12}$

Democracy as a political system has developed in its implementation. There are many models and variants of democracy, which are caused by the perspective of the meaning of substantial democracy. Democracy has developed into many variants, due to the dynamics of the political and legal process. Political law is how the law will and should be made and its direction determined in national politics and how the law is functioned to guarantee democracy. ${ }^{13}$

The parties involved in the political and legal process will be creative in designing procedural democracy practices following their culture, history, sociology, and interests. In the history of democratic theory, there is a sharp conflict between two different views. The first view is to interpret democracy as people's power, which means that citizens are involved in selfgovernment and self-regulation. The second view is to interpret democracy as granting power to the government through periodic voting.

There are two sharp conflicts regarding the view of democracy, thus giving birth to three models of democracy, namely: 1) Participatory democracy or direct democracy; 2) Liberal democracy or representative democracy; 3) Single party model democracy. This third democracy is still a polemic because it does not fulfill the requirements substantially. ${ }^{14}$

11 Ni'matul Huda, Dinamika Ketatanegaraan Indonesia Dalam Putusan Mahkamah Konstitusi, Yogyakarta, FH UII Press, 2011, page.186.

12 Ibid, page. 187.

13 Mahfud MD, Pergulatan Politik Dan Hukum Di Indonesia, Yogyakarta, Gama Media, 1999, page.30.

14 David Held, Demokrasi Dan Tatanan Global Dari Negara Modern Hingga Pemerintahan Kosmopolitan, Yogyakarta, Pustaka Pelajar, 2004, page. 4-7. 
In the context of regional head elections, both governors, regents, and mayors, the electoral system apply a democratic concept. This refers to the 1945 Constitution of the Republic of Indonesia, Article 18, Paragraph (4), which states that: "The Governor, Regent and Mayor respectively as Head of Provincial, Regency, and City Governments are elected democratically". Furthermore, at the level of implementation, the law regulating the election of regional heads, both governors, regents, and mayors, is applied normatively and empirically, is the concept of direct democracy.

The concept of regional head elections, both governors, regents, and mayors, is applied normatively and empirically is the concept of direct democracy. The concept and practice of direct election, starting from 2005 until now, is a critical evaluation of the concept of indirect election through representatives represented by Provincial or District and City Regional Representative Bodies.

The preferences of political parties on the concept and implementation of direct regional head elections, both governors, regents, and mayors, tend to exercise pragmatic political stance choices. A pragmatic attitude is interpreted as the best choice for mutual interests and to minimize risks. ${ }^{15}$

In this paper, we will only criticize the selection of candidate pairs for Regent and Candidate for Deputy Regent as well as pairs of Candidates for Mayor and Candidates for Mayor directly, with a Single Candidate as regulated in Law Number 10 of 2016 concerning the Second Amendment to Law Number 1 of 2015 Regarding the Stipulation of Government Regulation instead of Law Number 1 of 2014 concerning the Election of Governors, Regents and Mayors into Law. This is because, in the direct election of Candidates for Regent and Deputy Regent as well as Candidates for Mayor and Candidate for Deputy Mayor directly, public participation is easier to observe, monitor, and evaluate because it only involves 1 Regency or 1 City area, which is relatively more affordable. and with the number of residents and the number of permanent voters that are relatively small in comparison to the Province and with the number of residents and the number of permanent voters for the election of the Governor.

The provisions of Article 54 C, Paragraph (1), Letter: a, b, c, d, e, and Paragraph (2) of Law Number 10 of 2016 Concerning the Second Amendment to Law Number 1 of 2015 concerning Stipulation of Regulations Government instead of Law Number: 1 the year 2014 concerning the Election of Governors, Regents, and Mayors Into Laws, which regulates the procedure: "The determination of 1 (one) candidate pair for Regent and Candidate for Deputy Regent as well as pairs of Candidates for Mayor and Candidate for Deputy Mayor by District / City General Election Commission for the election of Regent and Mayor pairs. The previous law, namely Law Number: 8 of 2015 concerning Amendments to Law Number: 1 of 2015 concerning Stipulation of Government Regulations instead of Law Number: 1

15 Ikrar Nusa Bhakti, Menjauhi Demokrasi Kaum Penjahat Belajar Dari Kekeliruan NegaraNegara Lain, Bandung, Mizan, 2001, page. 193. 
of 2014 concerning the Election of Governors, Regents, and Mayors Into Law, the provisions of Article 52, Paragraph $(2,3,4,5,6)$, Article 53, Paragraph $(1,2,3,4)$, regulate the procedures for: "The determination of at least 2 (two) pairs of Candidates for Regent and Candidate Deputy Regent and Candidate pair for Mayor and Candidate for Deputy Mayor by the General Election Commission of the Regency / City for election, the pair of Regent and the pair of Mayor ".

From the provisions of the 2 (two) laws, it regulates the same thing, namely regarding "the determination of candidate pairs for Regent and Candidate for Deputy Regent as well as Candidate pairs for Mayor and Candidate for Deputy Mayor by the Regency / City General Election Commission for election, the pair of Regent and pair of Mayor" . The only difference lies in the minimum or least number of pairs that will be determined by the Regency / City General Election Commission. The difference in the minimum amount determined by the two laws is not just a difference in numbers and the difference in numbers between 2 pairs then becomes 1 pair. The difference in the number of pairs that have been legitimized through the amendment of the Law by allowing 1 partner will have an impact and influence as well as a contribution to the potential for empirical democracy with the preferences of political parties pragmatically.

Amendment of the Law is a political product, which is not born in a vacuum. Amendments to the Law, in fact, are not solely due to considerations of improvement based on implementation evaluations that cause problems. Considerations for improvement should be based on objective considerations and must be minimized by the interests of the legislators.

Amendments to the Law can be caused by several problems that arise, for example: inefficient, ineffective, difficult to implement, contains elements of discrimination, takes sides with certain interests, violates human rights, violates morals, ethics, religion and the Law. The basis of the Republic of Indonesia in 1945, creates social chaos, there are fundamental conflicts and principles between laws of different types or which are correlated, there is no legal certainty, creates multiple legal interpretations or ambiguity of legal interpretations, creates a potential legal vacuum and creates legal loopholes that can be used as an opportunity to circumvent the law. So amendments to the Law should be based on objective considerations as mentioned above.

In fact, the amendment to the Law is a political agreement between Legislators and the Executive (Government). The agreement is formed because of the prologue and dialogue that is not simple. Pull and pull interests collaborate with each other for alignment of each of the same interests to fight the collaboration of different interests. Until finally it resulted in a collective agreement as to the culmination of a combination of all interests to be formulated into a law. In connection with the dynamic changes in the Law on the Election of Governors, Regents, and Mayors, it can be criticized regarding the interests and sides of the Lawmakers. In addition, it can also carry out an analysis of the implementation to realize 
empirical democracy and the preferences of political parties in utilizing the legitimacy of the Single Candidate for the election of Regent and Deputy Regent Candidates as well as Mayor and Deputy Mayor Candidates.

The purpose of the research is to find out and analyze normative democracy which is only oriented to idealistic ideas or thoughts at the philosophical level. On the other hand, empirical democracy is the implementation of normative democracy in the practice of the state.

\section{B. RESEARCH METHODS}

The approach method used in this legal research is normative juridical. Normative juridical research is research that is focused on examining the application of the rules or norms in positive law. ${ }^{16}$ Legal research is a scientific activity based on methods, mathematics and certain thoughts that aim to study something or certain phenomena of law, by analyzing it. In addition, there is also an in-depth examination of these legal factors, to then try to solve the problems that arise in the symptoms concerned. ${ }^{17}$

\section{RESULT AND DISCUSSION}

\section{Democracy, Normative Democracy, and Empirical Democracy}

The terminology of democracy is very much and is a fundamental thought about the Government System. Various terminology about democracy can be concluded that: "Democracy is a form of government by the people". The quality of democracy is very much influenced by the conditions: economic, social, and cultural of the citizen so that it will produce important issues regarding the impact of the implementation of democracy.

Important issues concerning democracy include, who is meant by the people, what type of participation is suitable for the people, conditions that are conducive to realizing people's participation, costs and benefits of participation, how broad is the scope of government for people's participation, legal legitimacy in democracy, channels and a forum for differences of opinion in democracy and legal structures in handling disputes over the implications of democracy. ${ }^{18}$

The implementation of democracy is not only about theory or norms, but must also be based on philosophy. Philosophy will teach about the nature of a democracy, by providing formulas and the best ways to build a government. The ethical-moral factor is the main foundation for the philosophy of democracy. Apart from the two things mentioned above, the administration of democracy must be accumulated with an understanding of the practical experience of organizing governance in different societies and at different times. These three

16 Jhonny Ibrahim, Teori dan Metodologi Penelitian Hukum Normatif, Bayumedia Malang, 2011, page. 295

17 Zainuddin Ali, Metode Penelitian Hukum, Sinar Grafika, Jakarta, 2014, page. 18

18 George Sorensen, Demokrasi Dan Demokratisasi, Yogyakarta, Pustaka Pelajar, 2014, page.12. 
factors are intertwined in a complex manner so that democracy has an important element in the dynamics of government which requires high people's participation. ${ }^{19}$

The terminology of normative democracy is democracy which is ideally intended to be implemented by a nation-state, by adhering to the implementation of "governance of the people, by the people and for the people" and this implementation is manifested in the state constitution. Normative democracy in each country is different from one another because it is based on the ideology of each country. The Indonesian state develops forms and models of democracy that are different from liberal democracy and communist democracy. Democracy following the ideology of the Indonesian nation is Pancasila Democracy. Pancasila democracy has cultural and personal characteristics of the Indonesian nation as local wisdom which is then embodied in the State Constitution and State Ideology.

In a normative democracy, the state creates pillars of power which are divided into three so-called trias political principles, namely: Legislative, Executive, and Judicial powers. The three powers have their duties and functions to realize the functions and principles of checks and balances. The history of thinking about the existence of normative democracy originates from the history of the struggle for the realization of human rights. The emergence of normative democracy was a reaction to the bad experiences of the Monarchy and Dictator Government model. $^{20}$

Normative democracy, in the process of its birth, must be based on philosophical thinking about the meaning of democracy. This is intended to realize noble values that can be adopted into normative democratic provisions. Normative democracy is embodied in the state constitution, which is an ideal idea to limit the power of the Government and does not justify arbitrary actions by the Government to its citizens. A democratic government system does not centralize government to one hand but distributes it to other Bada-Bodies based on its main tasks and functions. A democratic government system always applies the rechtstaat principle and rule of law.

Empirical democracy is democracy in the meaning of the implementation of normative democracy which is based on a democratic philosophy. Empirical democracy has an equivalent and linear correlation with democratic practices. The practice of democracy which is based on the philosophy of democracy will give birth to an understanding and experience of a democracy which has dimensions of public participation in a broad and fair manner. ${ }^{21}$

This empirical democracy correlates with the meaning of democracy according to Joseph Schumpeter, which defines democracy as a political method and a mechanism for electing political leaders. Citizens

19 Ibid, page. 3 .

20 Aidul Fitriciada Azhari, Menemukan Demokrasi, Surakarta, UMS Press, 2005, page. 35 .

21 David Held, Models of Democracy, Cambridge, Polity Press, 2001, page. 20 . 
are allowed to vote for the best. Leaders - Political leaders who compete to win votes to become winners. The ability and opportunity to be able to choose among political leaders is called democracy. ${ }^{22}$

David Held provides a more comprehensive terminology of democracy, which David Held calls Democratic Autonomy, which states that Democratic Autonomy is defined as direct substantial participation in Local Community Institutions. The implementation of this democratic autonomy demands state accountability to commit to granting civil and political rights to citizens. According to David Held, Democratic Autonomy requires human rights or a bill of rights beyond the right to vote, to provide equal opportunities to participate and find personal preferences in the economic and social fields. ${ }^{23}$

The terminology of democracy, according to both David Held and Joseph Schumpeter, is to give meaning to empirical democracy or substantial democracy. Empirical democracy is "how democracy should be" not "What is democracy". So empirical democracy is oriented towards the implementation and implementation of democracy in governance practices. Empirical democracy always runs contextually and dynamically. On the other hand, normative democracy is an entity that is rich in definitions and terminology which always has the potential to become the subject of discussion and even critical analytical debate.

Efforts to form political democracy require preconditions for the pre-conditions to achieve a good political democracy. The prerequisites needed include the stable and good economic, social and cultural conditions of the community. Democracy will not run well when the economic, social, and cultural conditions of the community are not yet stable. This causality relationship, then Seymour M. Lipset stated that "The richer a nation is, the greater the chance for that country to carry out democracy".

The formation of political democracy always requires preconditions that support the birth of democracy, namely economic, social and cultural stability. Conversely, economic, social, and cultural stability will also encourage the birth of a healthy and dynamic political democracy. Both - both are dynamic entities and are variables that depend on one another. Therefore, for most developing countries, the issue of democracy, either normative democracy or empirical democracy, has always been a problem and a long debate between citizens and the state. The commitment of a democratic state must be realized without having to wait for the prerequisites for economic, social, and cultural stability. It is in such conditions that the state is in a position of "democratization process", with all its advantages and disadvantages. The democratization process is an effort to guarantee the civil and political rights of citizens. ${ }^{24}$

22 Georg Sorensen, Opcit . page. 15 .

23 David Held, Op.cit . page. 78 .

24 David Lehmann, Democrazy and Development, Cambridge, Polity Press, 1990, page. 89. 
The existence of democracy is a political process, therefore the existence of democracy, when interpreted from its quality, has different gradations. The democracy that is carried out by the Indonesian state is Pancasila democracy, which in its norms and its implementation must be imbued with and integrated with the principles of Pancasila. Pancasila democracy places democratic rights in harmony and balance with democratic responsibilities. Deliberation to reach consensus is the main feature of Pancasila democracy to bring together differences of opinion. ${ }^{25}$

\section{Politics, Political Parties, and General Elections}

Political terminology is everything related to matters concerning the interests of a group of people in a country. In general, politics has 2 meanings, namely politics in the sense of public interest or called politics and politics in the sense of policy or policy. Politics in the meaning of politics is a series of principles, principles, conditions, paths, methods, or tools that will be used to achieve goals. On the other hand, politics in the sense of policy means the use of certain considerations that can guarantee the implementation of efforts to realize the desires and ideals desired.

Political Science, defines politics as the process of forming and distributing power in society, including in the form of a decision-making process within the state. Political practice interprets politics as an art and science to gain power constitutionally and non-constitutionally. ${ }^{26}$

Political terminology is everything related to matters concerning the interests of a group of people in a country. In general, politics has 2 meanings, namely politics in the sense of public interest or called politics and politics in the sense of policy or policy. Politics in the meaning of politics is a series of principles, principles, conditions, paths, methods, or tools that will be used to achieve goals. On the other hand, politics in the sense of policy means the use of certain considerations that can guarantee the implementation of efforts to realize the desires and ideals desired.

Political Science, defines politics as the process of forming and distributing power in society, including in the form of a decision-making process within the state. Political practice interprets politics as an art and science to gain power constitutionally and non-constitutionally. ${ }^{27}$

Political terminology is everything related to matters concerning the interests of a group of people in a country. In general, politics has 2 meanings, namely politics in the sense of public interest or called politics and politics in the sense of policy or policy. Politics in the meaning of politics is a series of principles, principles, conditions, paths, methods, or tools that will be used to achieve goals. On the other hand, politics in the

25 Afan Gaffar, Politik Indonesia Transisi Menuju Demokrasi, Yogyakarta, Pustaka Pelajar, 1999, page. 115.

26 Miriam Budiardjo, Dasar-Dasar Ilmu Politik, Jakarta, P.T. Gramedia Pustaka Utama, 1995, page. 16-19.

27 Eman Hermawan, Politik, Teori, Kritik dan Nalar, Yogyakarta, Yayasan Klik, 2001, page. 71. 
sense of policy means the use of certain considerations that can guarantee the implementation of efforts to realize the desires and ideals desired.

Political Science, defines politics as the process of forming and distributing power in society, including in the form of a decision-making process within the state. Political practice interprets politics as an art and science to gain power constitutionally and non-constitutionally. ${ }^{28}$

There are 2 (two) aspects contained in a Political Party, namely: 1) A group of people who come together to agree on joint efforts for the national interest to create public welfare, based on mutually agreed upon special principles. 2) A group whose members agree to cooperate in the struggle for political power.

The existence of political parties is the main pillar that supports the democracy of a country. This is because the existence of political parties is the main variable to measure the existence of democracy in a country. Political parties carry out democracy through a constitutional power struggle mechanism that involves citizen participation.

According to Jimmy Asshiddiqie, political parties have a very important position or status and role, namely: 1) Political parties as a very strategic link between government processes and/or state institutions and citizens. 2) Political parties greatly determine the quality of democracy. 3) Political parties are a form of institutionalization as a form of expression of ideas, thoughts, views, and free beliefs in a democratic society. 4) Political parties act as intermediaries in the processes of state decision-making. 5) Political parties are the only economic or political means of forming a collective will. ${ }^{29}$

Political parties as political instruments have several kinds of functions, including 1) Conducting political socialization. 2) Conducting political relations, both between the Head of the Political Party and its Members, as well as with other Political Parties or with the Government at all levels. 3) Fostering public opinion, that a political party is good, which will be able to defend the interests of the people so that the political party in the eyes of the people is a party that defends and helps the people. 4) Defend the interests of the people, channel people's aspirations, and supervise Government policies so that they are in line with the interests of the people. 5) As a political recruitment forum, namely the selection and selection and appointment of a person or group of people to carry out several roles in the political system. 6) As a political communication because political parties carry out the process of delivering information about politics from the Government to the Community and from the Public to the Government. 7) As conflict control, political parties carry out conflict control, starting from

28 Miriam Budiardjo, Op. cit. page. 160.

29 Jimly Asshiddiqie, Kemerdekaan Berserikat, Pembubaran Partai Politik dan Mahkamah Konstitusi, Jakarta, Sekretaris Jendral dan Kepaniteraan Mahkamah Konstitusi, 2006, page. $52-55$. 
differences of opinion to physical disputes between individuals or groups. $^{30}$

\section{CONCLUSION}

Normative democracy is only oriented to idealistic ideas or thoughts at the level of philosophy. On the other hand, empirical democracy is the implementation of normative democracy in the practice of the state, governance, and political system. Observing the implementation of democratic practices, between normative democracy and empirical democracy, it is not always parallel, even a condition of legal anomalies can occur. In this reality, the term normative democracy is called the essence of democracy, and empirical democracy is called performance democracy. The link between normative democracy and empirical democracy, in law, is called the gap between das sollen and das sein. Political parties are political organizations or groups that are organized and live a certain ideology and are formed with a specific purpose, whose Members have the same orientation, values, and ideals, and have the aim of gaining political power in a constitutional way to implement policies - Their policies. The constitutional way is carried out through general elections using political mechanisms which are legitimized as a form of democracy.

\section{BLIBIOGRAPHY}

\section{Books :}

Afan Gaffar, 1999, Politik Indonesia Transisi Menuju Demokrasi, Yogyakarta, Pustaka Pelajar, Yogyakarta;

Aidul Fitriciada Azhari, 2005, Menemukan Demokrasi, UMS Press, Surakarta;

David Held, 2001, Models of Democracy, Polity Press, Cambridge;

2004, Demokrasi Dan Tatanan Global Dari Negara Modern Hingga

Pemerintahan Kosmopolitan, Pustaka Pelajar, Yogyakarta;

2007, Models of Democracy, Terjemahan Abdul Haris, Akbar Tandjung Institute, Jakarta;

Eman Hermawan, 2001, Politik,Teori, Kritik dan Nalar, Yayasan klik, Yogyakarta;

Georg Sorensen, 2004, Demokrasi Dan Demokratisasi, Pustaka Pelajar, Yogyakarta;

Ikrar Nusa Bhakti, 2001, Menjauhi Demokrasi Kaum Penjahat Belajar Dari Kekeliruan Negara-Negara Lain, Mizan, Bandung;

Jimly Asshiddiqie, 2006, Kemerdekaan Berserikat. Pembubaran Partai Politik dan Mahkamah, Konstitusi, Sekretaris Jendral dan Kepaniteraan Mahkamah. Konstitusi, Jakarta;

30 Sukarna, Sistem Politik, Bandung, PT. Citra Aditya Bakti, 1990, page. 45-56 . 
Jhonny Ibrahim, 2011, Teori dan Metodologi Penelitian Hukum Normatif, Bayumedia Malang;

Jonathan Wolff, 2013, Filsafat Politik, Nusamedia, Bandung;

David Lehmann, 1990, Democrazy and Development, Polity Press, Cambridge;

Mahfud MD, 1995, Pergulatan Politik Dan Hukum Di Indonesia, Gama Media, Yogyakarta;

Miriam Budiardjo, 1995, Dasar-Dasar Ilmu Politik, PT. Gramedia Pustaka Utama, Jakarta;

Ni'matul Huda, 2011, Dinamika Ketatanegaraan Indonesia Dalam Putusan Mahkamah Konstitusi, FH UII Press, Yogyakarta;

Sukarna, 1990, Sistem Politik, PT.Citra Aditya Bakti, Bandung;

Zainuddin Ali, 2014, Metode Penelitian Hukum, Sinar Grafika, Jakarta;

\section{Journals :}

A. Ganu Kadir, Dinamika Partai Politik, Sosiohumaniora Journal, Volume 16 Number 2 Juli 2014;

Agus Nurulyam Suparman, Gilang Yuniar Rahman, Partai Politik dan Kaderisasi, Moderat Journal, Volume Number 4, 2017;

Aiyub Mohsin, Partai Politik dan Sistem Demokrasi di Indonesia, Populis journal, Volume 3 Number 6, 2018;

Ida Musofiana, Legal Protection For Victims Of Cybercrime In The Digital Era In Strengthening Cyber Democracy In Indonesia Post 2019 General Election, The 2nd Proceeding International Conference And Call Paper Sultan Agung Islamic University, "democracy in digital era : law, governance, sociall and economic perspective in Asia, Australia and Dutch". Volume 1. Number 1. 2020;

Ramly Hutabarat, Peranan Partai Politik Menyerap Aspirasi Masyarakat dan Hukum Politik yang Tidak Simantik, Hukum dan Pembangunan Journal, Volume 35 Number 3, 2005;

Ridho Imawan Hanafi, Kemunculan dan Tantangan Partai Politik Baru Pada Pemilu 2019, Penelitian politik Journal, Volume 15. Number 2. December 2018;

Udiyo Basuki. Parpol, Pemilu dan Demokrasi : Dinamika Parta Politik Dalam Sistem Pemilihan Umum di Indonesia Dalam Perspektif Demokrasi, Kosmik Journal, Volume 20. Number 2. 2020;

Zaenal Abidin Saleh, Democracy and Political Parties, Legislasi Indonesia Journal, Volume 5. Number 1. Maret 2008; 